\title{
Cancer Death Rate
}

National Cancer Institute

\section{Source}

National Cancer Institute. Cancer Death Rate. NCI Thesaurus. Code C19701.

Mortality due to cancer. 